\title{
Strategi Pemasaran Produk Mainan Anak-Anak dari Limbah Kayu PT Safira Tumbuh Berkembang
}

\author{
Marketing Strategy of Toy Products Made of Wooden Waste at \\ PT Safira Tumbuh Berkembang
}

\author{
Naomi Dongoran ${ }^{1 *}$, Ma'mun Sarma $^{2 \sharp}$, dan Budi Suharjo ${ }^{3 *}$ \\ ${ }^{1}$ Kementerian Lingkungan Hidup dan Kehutanan \\ Gd. Manggala Wanabakti Blok 1 lt. 14 Jl. Gatot Subroto, Jakarta Pusat 10270 \\ ${ }^{2}$ Departemen Manajemen, Fakultas Ekonomi dan Manajemen, Institut Pertanian Bogor \\ ${ }^{3}$ Departemen Matematika, Fakultas Matematika dan Ilmu Pengetahuan Alam, Institut Pertanian Bogor \\ \#Jl. Kamper, Kampus IPB Dramaga, Bogor 16680
}

\begin{abstract}
ABSTRAK
Semakin tahun sumber daya alam (SDA) berupa kayu semakin berkurang, sehingga perlu pemanfaatan kayu seefisien mungkin, maka pemanfaatan limbah kayu menjadi penting. Salah satu perusahaan yang mengolah dan memanfaatkan limbah kayu menjadi bernilai ekonomis adalah PT Safira Tumbuh Berkembang (PT STB) di Bogor. Tujuan penelitian ini: (1) mengidentifikasi faktor-faktor yang mempengaruhi proses pengambilan keputusan pembelian, dan (2) menyusun strategi pemasaran yang direkomendasikan untuk pengembangan usaha. Dalam penelitian ini yang menjadi populasi adalah orang tua murid dan guru dari 10 Taman Kanak-Kanak (TK) di Kota Bogor. Contoh ditentukan dengan teknik purposive sampling, dengan pertimbangan mudah didatangi dan TK tersebut bersedia diwawancarai. Dari setiap TK diambil 6 responden yang terdiri dari 3 orang tua murid dan 3 guru TK, sehingga jumlah responden 60 orang. Metode analisis data yang digunakan adalah Thurstone, dengan pertimbangan kajian yang dilakukan untuk menggali perilaku konsumen dalam pengambilan keputusan. Dari pertimbangan terhadap analisis atribut prioritas yang paling diinginkan konsumen disusun strategi pemasaran: (1) menurunkan harga sebesar 9,34\% dari harga yang telah ditetapkan perusahaan, (2) meningkatkan disain baru yang sesuai dengan keinginan anak-anak usia 2-6 tahun dan tetap mempertahankan variasi produk yang terdapat pada PT STB; (3) mempertahankan mutu sekaligus meningkatkan mutu yang telah ada sesuai dengan usia anak 2-6 tahun sebagai salah satu keunggulan perusahaan; (4) mempertahankan dan mengembangkan kandungan unsur pendidikan dan kombinasi warna cerah pada mainan anak-anak sebagai keunikan atau ciri khas dari desain yang diproduksi PT STB; (5) mengembangkan promosi melalui interaksi langsung antara penjual dengan target (personal selling) pada sekolah TK potensial dan melalui iklan pada majalah anak-anak seperti Bobo, Donald Bebek dan Taboloid Kids dan (6) mengembangkan tempat penjualan yang ada saat ini melalui menjalin kerjasama dengan toko mainan anak-anak yang terdapat pada pusat perbelanjaan/pertokoan dan sekolah taman kanak-kanak potensial dalam pemasaran produk kepada orangtua murid.
\end{abstract}

Kata kunci: limbah kayu, produk mainan anak-anak, strategi pemasaran

\section{ABSTRACT}

After year such a natural resources as wood becomes rare, so its use needs to be to the most efficient way, in line with it, wooden waste use becomes important. One of the companies which processes and makes use of the wooden waste to be children toys of economical value in Bogor is PT Safira Tumbuh Berkembang (PT STB). The research objectives are (1) to identify factors that influence a consumer's decision making, and (2) to set a recommended marketing strategy to develop the business. The population In this research is students' parents and teachers of 10 kindergartens in the City of Bogor. Samples were determined by purposive sampling, with consideration of easily accessible and the TK is

\footnotetext{
*) Korespondensi:

Gd. Manggala Wanabakti Blok 1 lt. 14 Jl. Gatot Subroto, Jakarta Pusat 10270; E-mail: setbp2sdmk@dephut.go.id
} 
willing to be interviewed. From each kindergarten a sample of 6 respondents comprising 3 parents and 3 teachers is taken, in order to make the total number of respondents of regarding 60 people. Data analysis method used is Thurstone, with consideration of a study conducted to explore consumer behavior in decision making. From the above analysis, the marketing strategy to do are as follows: (1) to lower the price of $9.34 \%$ of the set price, (2) To improve a new design in accordance with educational content element and bright colors combination on the toy, (3) to maintain the quality in accordance with the market segment, (4) maintain and develop the educational element content and a combination of bright colors found in children's toys as unique or characteristic of the designs produced by PT STB, (5) To develop promotion through direct interaction between sellers and the targets (personal selling) in a potential kindergarten as well as (6) To develop selling points through cooperation with children toy stores in malls/shopping centers.

Key words: marketing strategy, children's toys, wooden waste

\section{PENDAHULUAN}

Persediaan bahan baku kayu yang berasal dari hutan alam semakin tahun semakin berkurang, menyadari hal tersebut pada tahun 1980 an, pemerintah dalam hal ini Departemen Kehutanan mendorong penanaman Hutan Tanaman Industri (HTI). Namun demikian sampai tahun 1990-an, kebutuhan bahan baku industri jauh lebih besar dibandingkan pasokan bahan baku yang berasal dari hutan alam dan HTI serta hutan rakyat. Dalam kondisi yang demikian, salah satu cara mengatasinya dengan memanfaatkan limbah kayu secara maksimal (Litbang Kehutanan, 2003). Limbah kayu tersebut tersebar di areal penebangan/eksploitasi dan di lokasi industri. Pemanfaatan limbah sebetan kayu dapat memberikan nilai tambah berupa substitusi bahan baku mebel, penyerapan tenaga kerja, pengelolaan lingkungan, pendapatan masyarakat/pemerintah dan keuntungan bagi pengusaha industri kecil pembuatan produk kayu lamina (Purwanto, 2011).

Menurut Litbang Kehutanan (2005), pemanfaatan limbah kayu industri meubel dan furniture dapat meningkatkan penerimaan perusahaan, serta penyerapan tenaga kerja. Perusahan penggergajian, meubel dan furniture biasanya hanya memanfaatkan limbah 5-10\%, sedangkan sisanya terbuang begitu saja atau dijual dengan harga sangat murah. Limbah yang terbuang tersebut apabila dimanfaatkan akan bernilai ekonomis.

PT Safira Tumbuh Berkembang (PT STB) merupakan salah satu perusahaan yang bergerak memproduksi mainan anak-anak, yang dengan kecermatannya mengolah dan memanfaatkan kayu bekas atau limbah kayu sebagai bahan baku produknya menjadi bernilai ekonomis. Dalam pengembangan usahanya, PT STB memasarkan produk hasil desain sendiri lewat Internet, yaitu memperkenalkan produk dan fasilitas yang terdapat pada PT STB kepada konsumen yang ingin tahu lebih banyak tentang perusahaan. Dengan membuka website PT STB, konsumen dapat mengadakan janji dengan perusahaan untuk berkunjung ke sekolah mempresentasikan dan mendemonstrasikan berbagai produk PT STB. Pada saat sekolah yang dikunjungi tertarik dengan presentasi yang disampaikan, maka pada kesempatan tersebut sekolah menyepakati melakukan kunjungan ke PT STB. Pemasaran lain yang dilakukan PT STB adalah mengikuti pameranpameran, baik pameran besar maupun bazaar pada tempat tertentu. Melalui pameran, biasanya konsumen memesan (order) beberapa produk yang dihasilkan PT STB. Dengan berbagai pemasaran yang dilakukan Rumah Abia, khususnya pemasaran dalam negeri (domestik), seyogyanya jika dikaitkan dengan faktor penawaran dan permintaan. pemasaran produk mainan anakanak dari limbah kayu berkembang dan prospeknya menjanjikan atau cerah, karena jumlah dan tingkat pertumbuhan anak usia 2-6 tahun meningkat setiap tahunnya yaitu sekitar $27 \%$ (BPS, 2009).

Beberapa masalah yang dihadapi perusahaan adalah sistem produksi mainan anak hanya satu kali produksi untuk setiap jenis desain mainan anak yang dibuat dan desain yang menumbuhkan kreatifitas anak terbatas, sehingga pada waktu konsumen menginginkan suatu produk mainan anak yang sama, sering kali sudah tidak diproduksi Rumah Abia; sebagian besar produk mainan anak ditetapkan dengan harga tidak terjangkau masyarakat pada umumnya. Permasalahan yang dihadapi konsumen dapat diduga bahwa konsumen kurang mengenal atau bahkan tidak mengetahui produk mainan anakanak PT STB dan jenis produk yang dipasarkan; 
keterbatasan informasi yang diperoleh konsumen dimungkinkan menjadi penyebab kurang atau belum dikenalnya produk PT STB; desain mainan anak berupa puzzle (bongkar pasang) yang dapat mempercepat dan menguatkan kemampuan mengasah motorik dan kreativitas anak belum disesuikan dengan kemampuan anak Indonesia pada umumnya, sehingga anak-anak hampir tidak bisa menyusun mainan puzzle tersebut yang lama kelamaan menimbulkan kebosanan. Selain itu, mainan anak dari bahan lain seperti plastik atau logam atau playstation (vedio game) menjadi mainan anak pilihan alternatif yang dipilih konsumen.

Tujuan penelitian ini: (1) Mengidentifikasi faktor-faktor yang memengaruhi tingkat pengenalan konsumen terhadap produk mainan anakanak dari limbah kayu pada PT STB/Rumah Abia, dan (2) Menyusun strategi pemasaran pengembangan usaha produk mainan anak-anak dari limbah kayu PT STB (Rumah Abia).

\section{METODE PENELITIAN}

Lokasi tempat penelitian adalah PT STB yang berlokasi di Jl K.H. Moch Toha 13 Ciawi Kecamatan Ciawi Kabupaten Bogor. Populasi dalam penelitian ini guru dan orang tua murid Taman Kanak-kanak (TK) di Kota Bogor. Contoh ditentukan berdasarkan pertimbangan (purposive sampling), yaitu contoh yang disengaja dengan pertimbangan mudah didatangi dan TK tersebut bersedia diwawancarai. Dari 132 jumlah TK yang terdaftar di kota Bogor, diambil 10 TK menurut pertimbangan di atas. Dari setiap TK diambil enam responden yang terdiri dari tiga orang tua murid dan tiga orang guru. Dengan demikian jumlah responden sebanyak 60 orang.

Metode analisis data yang digunakan adalah deskriptif-kualitatif dan kuantitatif. Metode kualitatif digunakan untuk mengetahui faktor-faktor yang memengaruhi konsumen dalam mengambil keputusan pembelian mainan anak dari limbah kayu. Untuk memudahkan interpretasi analisis digunakan tabel tabulasi.

Terdapat berbagai metode untuk mengetahui atribut prioritas yang paling dipentingkan konsumen, yaitu metode Fishbein, metoda Thurstone, pendekatan STP (segmenting, targeting dan positioning), Strengths, Weaknesses, Opportunities and Threats (SWOT) dan lainnya. Namun dalam penelitian ini digunakan metode analisis Thurstone, dengan pertimbangan bahwa kajian yang dilakukan adalah menggali perilaku konsumen dalam pengambilan keputusan pembelian produk mainan anak-anak. Tahapan metode Thurstone (Samian, 2008) adalah:

1. Membandingkan skala sikap terhadap peubah ke i dan ke j dengan memberi skor 1 ; jika $\mathrm{Vi}>$ $\mathrm{Vj}$; dan memberi nilai 0; jika $\mathrm{Vi}<\mathrm{Vj}$; serta memberi nilai 0.5 jika $\mathrm{Vi}=\mathrm{Vj}$.

2. Membuat Matrik Frekuensi, yaitu jumlah skor masing masing tiap peubah.

3. Membentuk matrik proporsi, dimana pembagian tiap unsur matriks frekuensi dengan total frekuensi.

4. Transformasi matriks proporsi ke nilai baku Z.

5. Hitung rataan tiap kolom tanpa menyertakan unsur dari diagonal matriks, kemudian kolom diurutkan mulai dari kolom dengan rataan kecil ke besar.

6. Menghitung selisih kolom terdekat. Peubah dengan rataan tertinggi dikurangi dengan peubah dengan rataan yang lebih rendah. hasilnya merupakan jarak antara dua peubah yang saling berdekatan.

7. Hitung skala tiap peubah dengan menetapkan nilai skala pertama bernilai nol, maka nilai skala selanjutnya dihitung dengan cari nilai kumulatif dari nilai skala sebelumnya.

Penyusunan strategi pemasaran dalam studi ini didasarkan pada proses pengambilan keputusan konsumen (pengenalan kebutuhan, sumber informasi, evaluasi alternatif, keputusan pembelian, evaluasi pasca pembelian), dan prioritas atribut yang diinginkan konsumen sebagai pertimbangan dalam pembelian mainan anak-anak dari limbah kayu (Engel et al (1994).

\section{HASIL DAN PEMBAHASAN}

PT STB merupakan salah satu perusahaan yang bergerak di bidang mainan anak-anak, assesories anak dan furniture anak dari bahan dasar kayu. Perusahaan berdiri sejak tahun 1993 yang beralamat di Jl. Moh. Toha No. 13 Ciawi Bogor. Pada awalnya nama perusahaan adalah Four Corner dan kemudian berganti nama menjadi PT STB. PT STB mempunyai misi memanfaatkan limbah kayu sebagai bahan baku dalam memproduksi produk mainan anak-anak yang mempunyai nilai ekonomis. Visinya menjadikan produk PT STB sebagai produk mainan anak-anak edukatif yang membangun perkembangan kreativitas anak. 
Dalam memproduksi mainan anak-anak dari kayu, perusahaan sangat memperhatikan citra, fungsi dan ketertarikan anak-anak pada sebuah produk, sehingga desainnya lebih banyak menggunakan image atau fitur flora dan fauna. Hasil produksi PT STB dipajang pada outlet yang terdapat di dalam kompleks pabrik yang dinamai Rumah Abia. PT STB memanfaatkan sumber daya manusia (SDM) yang ada di daerah sekitar pabrik dengan jumlah tenaga kerja 24 orang. Penempatan pekerja disesuaikan dengan keterampilan yang dikuasainya.

Pemasaran ekspor hanya terjadi ke Swiss sejak tahun 2003. Pangsa pasar ekspor semakin tidak dapat diandalkan, sehingga perusahaan mulai melakukan mengembangkan pasar domestik. Ditengah perkembangannya, pada Januari 2008 perusahaan PT STB memperkenalkan Wisata Karya dengan sebutan perusahaan "Factory Chuting", yaitu anak mengenal lebih dekat proses produksi pembuatan suatu mainan melalui pengamatan proses pembuatan mainan.

Pemasaran produk yang dilakukan PT STB selama ini menggunakan (1) Media internet yaitu melalui website (rumah_abia.com) dan (2) Pameran, yaitu mengikuti pameran-pameran, baik pameran besar maupun bazar-bazar yang diselenggarakan Usaha Kecil Menengah (UKM) maupun pemerintah, seperti Pemerintah Daerah (Pemda) DKI, Perindustrian, dan lain-lain. Sasaran pasar dalam negeri PT STB adalah (1) Sekolah TK. Sekolah menjadi target pasar dari PT STB, karena sekolah dapat menggunakan produkproduk yang diproduksi oleh rumah Abia sebagai alat peraga dalam proses pembelajaran maupun sebagai mainan, assesories atau hiasan bagi sekolah; (2) Keluarga anak dan orang tua. Anak dan orang tua tentunya berhubungan erat saat memutuskan menggunakan suatu produk tertentu. Dengan ketertarikan anak terhadap produk apa yang ingin dimiliki, tentunya membuat orang tua ikut memutuskan apakah produk tersebut memang pantas dimiliki dan digunakan oleh anaknya.

Jenis kayu yang sering digunakan adalah kayu-kayu sisa atau limbah, karena bentuk produk mainan mayoritas kecil-kecil. Perusahaan dapat memanfaatkan dari kayu-kayu sisa dengan harga jauh lebih murah dibandingkan dengan harus menggunakan jenis kayu baru. Penggunaan bahan baku dari kayu sisa atau limbah dapat menguntungkan perusahaan sampai $80 \%$ dalam bahan baku kayu. Sumber bahan baku diperoleh dari perusahaan furnitur yang telah ekspor terdapat disekitar perusahaan, sebagai limbah kayu salah desain atau potong.

Untuk produksi mainan anak dan assesories kamar anak bisa mencapai 20.000-30.000 buah per tahun, sedangkan untuk furniture anak mencapai 15 buah per tahun. Produksi furniture anak dihitung berdasarkan jumlah permintaan konsumen, yakni dari pesanan konsumen yang ingin memiliki furniture khusus untuk kamar anaknya. Pada produksi furniture anak ini baru dimulai pada tahun 2008.

\section{Karakteristik konsumen}

Sebagian besar konsumen berusia 31-40 tahun $(38,3 \%)$, usia $20-30$ tahun $(36,7 \%)$ dan usia 41-50 tahun 25,0\%. Dilihat dari sisi pekerjaan, sebagian besar konsumen bekerja sebagai guru/ pegawai swasta $(56,7 \%)$, ibu rumah tangga (31,6\%), Pegawai Negeri Sipil (PNS) 6,7\% dan wiraswasta $5,0 \%$. Berdasarkan tingkat pendidikan, sebagian besar berpendidikan S1 (43,3\%) dan Diploma/Akademi $40 \%$. Jumlah keluarga terkait jumlah pengeluaran yang digunakan keluarga dalam mengkonsumsi atau membelanjakan barang dan jasa. Semakin besar jumlah anggota keluarga, biasanya kecenderungan pengeluaran semakin besar. Berdasarkan data, jumlah anggota keluarga antara 3-4 orang $46,7 \%$ dan jumlah anggota $5-6$ orang $31,6 \%$.

Berdasarkan jenis kelamin, semua responden atau $100 \%$ merupakan wanita, baik guru TK maupun orangtua murid. Dilihat dari sisi pengeluaran untuk membeli mainan anak-anak setiap bulannya, nampak sebagian besar $(38,3 \%)$ pengeluaran kurang dari Rp50.000, 33,4\% mengatakan pengeluarannya untuk mainan anakanak tidak menentu dan tergantung permintaan anak.

Berdasarkan penilaian skor status pekerjaan, pendidikan, pendapatan dan kelompok usia yang dikutip Angel et al (1995) dari Tabel A1 Charles B, Nam dan Mary G tentang kelas sosial, menunjukkan bahwa responden berada pada kelas sosial menengah bawah. Perilaku karakteristik responden berguna untuk analisis konsumen dalam mendesain program pemasaran dan untuk menganalisis pengenalan kebutuhan, proses pencarian, kriteria evaluasi dan pola pembelian produk, serta preferensi merek dan pengolahan media.

Proses Pengambilan Keputusan Pembelian 


\section{Pengenalan Kebutuhan}

Tahap awal yang menjadi pertimbangan konsumen dalam pembelian mainan anak-anak adalah pengenalan kebutuhan. Pengenalan akan kebutuhan dimulai dari pernah tidaknya mendengar produk yang akan dibeli. Berdasarkan hasil penelitian, hampir seluruh responden $(98,3 \%)$, responden sudah pernah mendengar produk mainan anak-anak dari limbah kayu di Rumah Abia dan telah pernah berkunjung ke Rumah Abia 73,3\% responden (44 dari 60 responden). Sejalan dengan Angel et al (1994) yang menyebutkan bahwa pengenalan kebutuhan tergantung dua faktor, yaitu (a) kebutuhan yang dikenali harus cukup penting, (b) konsumen harus percaya bahwa solusi bagi kebutuhan ada dalam batas kemampuan konsumen. Kebutuhan konsumen akan mainan anak dari limbah kayu menjadi sesuatu yang cukup penting, karena produk mainan tersebut memiliki keunggulan dari aspek pendidikan bagi anak, yang dapat merangsang kreativitas anak saat merakit berbagai mainan. Selain itu si anak dapat mengetahui bahwa limbah kayu dapat dimanfaatkan dan tidak terbuang begitu saja.

Berdasarkan faktor kemampuan, tidak semua kebutuhan yang dikenal dapat dimiliki konsumen, karena keterbatasan pengeluaran dalam pembelian mainan anak yang sebagian besar berkisar Rp50.000 per bulan. Dilihat dari bahan mainan anak-anak, sebagian besar (93,3\%) telah mengenal mainan anak-anak dari bahan plastik, 73,3\% telah mengenal mainan dari bahan kayu dan 38,3\% telah mengenal mainan dari bahan logam. Berdasarkan jenis mainan yang telah dikenal: (a) sebagian besar (98,3\%) konsumen telah mengenal mobil-mobilan, pistol, boneka dan masak-masakan; (b) 68,3\% mengenal jenis mainan kotak celengan berbagai motif (Tabel 1).

\section{Mencari Informasi}

Setelah pengenalan kebutuhan terjadi, maka pertimbangan kedua yang dilakukan konsumen adalah pencarian informasi dari suatu produk barang atau jasa yang ingin dibeli. Pencarian informasi yang dilakukan dapat bersifat internal yang melibatkan perolehan pengetahuan dari ingatan dan bersifat pencarian eksternal terdiri dari pengumpulan informasi dari pasar. Pencarian informasi internal biasanya digunakan oleh konsumen yang sudah pernah mengenal produk mainan anak-anak, tergantung pada kemampuan pengetahuan untuk mengingatnya. Sebagian besar informasi tentang produk mainan anak-anak dari limbah kayu yang diproduksi PT STB berasal dari pencarian informasi eksternal dari teman (38,3\%), internet 31,7\%, brosur $20,0 \%$ dan pameran $6,7 \%$.

Tabel 1. Jenis produk mainan anak-anak yang dikenal responden

\begin{tabular}{clcc}
\hline No. & \multicolumn{1}{c}{$\begin{array}{c}\text { Jenis mainan yang } \\
\text { dikenal }\end{array}$} & $\begin{array}{c}\text { Jumlah } \\
\text { (orang) }\end{array}$ & $\begin{array}{c}\text { Persentase } \\
(\%)\end{array}$ \\
\hline a & $\begin{array}{l}\text { Gantungan kunci dari } \\
\text { baju }\end{array}$ & 28 & 46,7 \\
b $\quad \begin{array}{l}\text { Berbagai pajangan } \\
\text { magnet kulkas }\end{array}$ & 36 & 60,0 \\
c $\quad \begin{array}{l}\text { Kotak celengan } \\
\text { berbagai motif }\end{array}$ & 41 & 68,3 \\
d $\quad \begin{array}{l}\text { Menyusun balok } \\
\text { bermotif }\end{array}$ & 29 & 48,3 \\
e $\quad \begin{array}{l}\text { Mobil-mobilan, pistol, } \\
\text { boneka dan masak- } \\
\text { masakan }\end{array}$ & 59 & 98,3 \\
f $\quad \begin{array}{l}\text { Lainnya (ayunan, } \\
\text { jungkitan, perosotan) }\end{array}$ & 19 & 31,7 \\
\hline & $\quad$ & \\
\hline
\end{tabular}

Berdasarkan sumber informasi, umumnya konsumen memperoleh sumber informasi komersial yang berasal dari internet, brosur dan pameran $61,7 \%$ dan sumber informasi pribadi, yaitu teman 38,3\%. Dari pengamatan, sumber informasi konsumen, 73,3\% telah berkunjung ke Rumah Abia, baik secara pribadi, keluarga ataupun dari sekolah.

Kunjungan terakhir ke Rumah Abia, sebagian besar konsumen (38,6\%) berkunjung ke Rumah Abia satu tahun lalu, sedangkan 27,3\% berkunjung enam bulan lalu dan 13,6\% berkunjung tiga bulan lalu. Dilihat dari sisi keinginan berkunjung ke Rumah Abia lagi, 53,3\% knsumen mengatakan ingin berkunjung dan tergantung waktu luang, 25\% mengatakan ingin berkunjung dengan alasan sekedar ingin tahu perkembangan, dan 21,7\% mengatakan sangat ingin berkunjung

Keinginan responden akan berbagai jenis mainan anak-anak di Rumah Abia sangat bervariasi (Tabel 2), dimana sebagian besar responden menyukai gantungan kunci, magnet panjang, kotak celengan berbagai motif, grumpy jery dan berbagai motif pajangan.

\section{Evaluasi Alternatif}

Pertimbangan yang dilakukan konsumen sebelum memutuskan untuk membeli adalah terlebih dahulu mengevaluasi produk yang akan dibeli, baik dari waktu pembelian, tempat membeli, kebiasaan konsumen dalam membeli suatu produk maupun pengambilan keputusan 
untuk membeli. Dalam hal ini, sebagian besar $(98,3 \%)$ pernah membeli mainan anak-anak dalam satu tahun terakhir dan hanya 1,7\% yang tidak membeli pada tahun yang sama.

Tabel 2. Jenis produk mainan anak-anak yang disukai responden di Rumah Abia

\begin{tabular}{|c|c|c|c|}
\hline No. & Jenis mainan disukai & $\begin{array}{l}\text { Jumlah } \\
\text { (orang) }\end{array}$ & $\begin{array}{c}\text { Persentase } \\
(\%) \\
\end{array}$ \\
\hline $\mathrm{a}$ & $\begin{array}{l}\text { Gantungan kunci } \\
\text { magnet panjang }\end{array}$ & 50 & 83,3 \\
\hline $\mathrm{b}$ & Grumpy jery & 37 & 61,7 \\
\hline c & $\begin{array}{l}\text { Kotak celengan berbagai } \\
\text { motif }\end{array}$ & 41 & 68,3 \\
\hline $\mathrm{d}$ & Berbagai motif pajangan & 40 & 66,7 \\
\hline $\mathrm{e}$ & Alat ukur tinggi badan & 34 & 56,7 \\
\hline $\mathrm{f}$ & $\begin{array}{l}\text { Menyusun potongan } \\
\text { kayu (puzzle) }\end{array}$ & 9 & 15,0 \\
\hline
\end{tabular}

Dilihat dari sisi kebiasaan membeli, 40,0\% konsumen membeli mainan dengan terlebih dahulu direncanakan dari rumah, 35\% membeli tergantung situasi dan $25 \%$ pembelian dilakukan secara mendadak. Pertimbangan konsumen dalam memilih tempat pembelian mainan anakanak, sebagian besar $(51,7 \%)$ memilih supermarket atau toko mainan anak-anak dan $48,3 \%$ konsumen membeli mainan di pedagang keliling/depan sekolahan. Dalam memutuskan pembelian, $45 \%$ anak-anaknya dan 31,7\% suami/istri (Tabel 3). Apabila dilihat dari waktu pembelian, 66,7\% konsumen akan membeli, jika anak minta mainan, $26,7 \%$ membeli pada waktu promosi di pameran dan sisanya $(6,6 \%)$ pada saat ada diskon.

\section{Keputusan Membeli}

\section{a. Kesan pelanggan}

Sebanyak $73,3 \%$ pernah membeli mainan anak dari limbah kayu di Rumah Abia, sedangkan lainnya belum pernah. Dari data yang pernah membeli, bahwa $88,6 \%$ membeli mainan di Rumah Abia, sedangkan 11,4\% saat pameran; Keputusan pembelian mainan $56,8 \%$ diputuskan oleh anak-anak, sisanya $(43,2 \%)$ diputuskan orang tua. Hasil penelitian Augustinah dan Herawati (2010), menunjukkan bahwa bentuk komunikasi keluargamempunyai pengaruh nyata terhadap pengaruh anak dalam keputusan pembelian.

Waktu pembelian mainan, dilakukan pada saat kunjungan ke Rumah Abia $(84,1 \%)$, saat pameran $9,1 \%$ dan pada saat anak minta mainan $6,8 \%$; Jenis mainan yang dibeli sebagian besar $(41,7 \%)$ jenis menyusun balok bermotif (puzzle) dan jenis kotak celengan/hiasan kamar anak
31,7\%; Dari frekuensi pembelian, 52,3\% berpendapat tidak tentu/tergantung kebutuhan anak sekolah; Dari sisi alasan membeli mainan, 65,9\% berpendapat menambah daya kreatif anak dan $25,0 \%$ karena mutu terjamin

Tabel 3. Pengambil keputusan dalam pembelian mainan anak-anak

\begin{tabular}{|c|c|c|c|}
\hline No & Uraian & $\begin{array}{l}\text { Jumlah } \\
\text { (orang) }\end{array}$ & $\begin{array}{c}\text { Persentase } \\
(\%)\end{array}$ \\
\hline $\mathrm{a}$ & Suami/istri & 19 & 31,7 \\
\hline $\mathrm{b}$ & Anak & 27 & 45,0 \\
\hline c & Teman & 3 & 5,0 \\
\hline d & Pedagang & 10 & 16,6 \\
\hline e & Inisiatif sendiri & 1 & 1,7 \\
\hline \multicolumn{2}{|c|}{ Jumlah } & & 100,0 \\
\hline
\end{tabular}

b. Alasan responden belum membeli mainan dari Limbah Kayu

Sebanyak $26,7 \%$ belum mengenal dan belum pernah berkunjung ke Rumah Abia. Hal ini berarti, upaya promosi yang dilakukan perusahaan melalui internet perlu mendapat perhatian dan diperbaiki.

c. Pendapat responden tentang harga

Pada saat wawancara dengan responden, peneliti membawa berbagai macam aneka mainan anak-anak dari limbah kayu yang di produksi PT STB, sehingga yang belum berkunjung ke Rumah Abia dapat memberikan pendapat tentang berbagai harga. Pada Tabel 4 diperlihatkan data hasil rekapitulasi pendapat konsumen tentang harga.

Secara umum harga yang diinginkan konsumen jauh lebih rendah daripada harga yang ditawarkan saat wawancara. Hal ini dapat dimengerti, karena pada umumnya kemampuan membayar (willingness to pay) lebih kecil dari harga yang ditawarkan. Hal penting dilakukan perusahaan untuk tetap mempertahankan pelanggan dan meningkatkan penjualan adalah penurunan harga menurut keinginan konsumen $(9,34 \%)$.

\section{Keinginan Konsumen}

\section{Evaluasi Pasca Pembelian}

Pada Tabel 5 diperlihatkan data rekapitulasi kepuasan responden yang mencakup keragaman produk, ketahanan produk, merek, lokasi pemasaran, kemudahan mencapai Rumah Abia, harga dan promosi yang telah dilakukan selama ini. 
Tabel 4. Pendapat responden tentang harga produk mainan di Rumah Abia

\begin{tabular}{|c|c|c|c|c|c|c|c|}
\hline No. & Jenis mainan & $\begin{array}{l}\text { Murah } \\
(\%)\end{array}$ & $\begin{array}{l}\text { Sedang } \\
(\%)\end{array}$ & $\begin{array}{c}\text { Mahal } \\
(\%)\end{array}$ & $\begin{array}{c}\text { Rerata harga yang } \\
\text { diinginkan (Rp) }\end{array}$ & $\begin{array}{c}\text { Harga saat } \\
\text { wawancara } \\
(\mathrm{Rp})\end{array}$ & $\begin{array}{l}\text { Jumlah murah } \\
\text { dan sedang (\%) }\end{array}$ \\
\hline 1 & $\begin{array}{l}\text { Gantungan Kunci/ } \\
\text { magnet }\end{array}$ & 31,7 & 63,3 & 5,0 & 4.506 & 5.000 & 95,0 \\
\hline 2 & Grumpy Jery & 13,3 & 65,0 & 21,7 & 14.208 & 15.000 & 78,3 \\
\hline 3 & $\begin{array}{l}\text { Kotak celengan } \\
\text { berbagai motif dan } \\
\text { tempat kartu nama }\end{array}$ & 1,7 & 50,0 & 48,3 & 23.701 & 25.000 & 51,7 \\
\hline 4 & $\begin{array}{l}\text { Berbagai motif } \\
\text { gantungan baju }\end{array}$ & 5,0 & 43,3 & 51,7 & 44.724 & 50.000 & 48,3 \\
\hline 5 & $\begin{array}{l}\text { Menyusun balok } \\
\text { bergambar dan alat } \\
\text { ukur tinggi badan }\end{array}$ & 0,0 & 20,0 & 80,0 & 90.875 & 100.000 & 20,0 \\
\hline 6 & $\begin{array}{l}\text { Mainan memasukkan } \\
\text { lempeng bulat ke } \\
\text { dalam lobang melalui } \\
\text { penarik tali }\end{array}$ & 0,0 & 11,7 & 88,3 & 90.875 & 150.000 & 11,7 \\
\hline
\end{tabular}

a. Kepuasan responden terhadap aneka ragam produk mainan dari kayu

Sebagian besar $(70,5 \%)$ konsumen berpendapat cukup puas dengan berbagai aneka ragam produk mainan anak-anak dari limbah kayu di Rumah Abia. Hal ini mengindikasikan bahwa perusahaan masih perlu mengembangkan aneka ragam produk di masa mendatang, agar pelanggan tidak beralih kepada produk mainan kayu dari pesaing.

b. Kepuasan responden tentang mutu produk mainan dari limbah kayu

Sebagian besar responden $(65,9 \%)$ berpendapat puas dengan kekuatan produk atau mutu mainan anak-anak dari limbah kayu di Rumah Abia. Kondisi mutu produk demikian mengakibatkan harga jual menjadi lebih tinggi. Hal inilah yang mengakibatkan produk PT STB harganya relatif lebih tinggi dibandingkan produk sejenis lainnya untuk pasar domestik. Meskipun mutu telah diakui konsumen, perusahaan tidak boleh lengah dan berpuas diri atau harus terus berinovasi mengembangkan mutu produk.

c. Kepuasan responden tentang unsur pendidikan Salah satu keunggulan Rumah Abia, menyediakan permainan dari kayu yang terkait dengan unsur pendidikan, seperti merakit bagian-bagian mainan menjadi satu kesatuan yang utuh, mendesain mainan anak-anak dengan motif atau gambar flora dan fauna yang memiliki unsur pendidikan pengenalan flora dan fauna kepada anak usia dini hingga merangsang kreativitas anak. Tabel 5 menunjukkan $75 \%$ konsumen cukup puas dengan unsur pendidikan yang diperoleh pada mainan anak-anak.

Menghasilkan produk-produk mainan anakanak dari limbah kayu yang memuat unsur pendidikan dapat merangsang motorik anak masih diperlukan dan terus ditingkatkan dalam pengembangan perusahaan.

d. Kepuasan responden tentang merek

Sebagian besar responden $(70,5 \%)$ berpendapat kurang puas dengan merek produk mainan dari limbah kayu di Rumah Abia. Hal ini mengindikasikan belum semua produk PT STB bermerek dan merek yang sudah ada saat ini kurang dikenal oleh konsumen domestik. Perusahaan masih perlu mempro-mosikan merek mainan anak-anak yang di-kembangkan dan perlu segera memberi merek pada produk yang belum diberi merek.

e. Kepuasan responden tentang lokasi pemasaran Sampai saat ini lokasi pemasaran produk mainan anak-anak dari limbah kayu masih dipasarkan di Rumah Abia. Tentang lokasi ini, $63,6 \%$ konsumen mengatakan tidak puas dan 15,9\% mengatakan kurang puas. Dari data tersebut, lokasi pemasaran perlu perhatian untuk pengembangan perusahaan atau lokasi pemasaran ditempatkan lebih dekat dengan konsumen, yaitu di lokasi pusat pertokoan atau perbelanjaan yang terdapat arena bermain anak-anak. 
Tabel 5. Tingkat kepuasan responden terhadap produk mainan anak di Rumah Abia

\begin{tabular}{|c|c|c|c|c|c|c|c|c|}
\hline No. & Uraian & $\begin{array}{c}\text { Sangat } \\
\text { Puas } \\
(\%) \\
\end{array}$ & $\begin{array}{l}\text { Puas } \\
(\%)\end{array}$ & $\begin{array}{c}\text { Cukup } \\
\text { puas } \\
(\%) \\
\end{array}$ & $\begin{array}{l}\text { Kurang } \\
\text { puas (\%) }\end{array}$ & $\begin{array}{c}\text { Tidak } \\
\text { puas } \\
(\%) \\
\end{array}$ & $\begin{array}{c}\text { Jumlah sangat } \\
\text { puas dan puas } \\
(\%)\end{array}$ & $\begin{array}{c}\text { Jumlah kurang } \\
\text { puas dan tidak } \\
\text { puas (\%) }\end{array}$ \\
\hline 1 & $\begin{array}{l}\text { Aneka ragam } \\
\text { produk }\end{array}$ & 2,3 & 9,1 & 70,5 & 18,2 & 0 & 11,4 & 18,2 \\
\hline 2 & Mutu produk & 6,8 & 65,9 & 18,2 & 6,8 & 2,3 & 72,7 & 9,1 \\
\hline 3 & Unsur pendidikan & 4,5 & 13,6 & 75,0 & 6,8 & - & 18,2 & 6,8 \\
\hline 4 & Merek & - & 6,8 & 20,5 & 70,5 & 2,3 & 6,8 & 72,7 \\
\hline 5 & Lokasi pemasaran & - & 9,1 & 11,4 & 15,9 & 63,6 & 9,1 & 79,5 \\
\hline 6 & $\begin{array}{l}\text { Kemudahan } \\
\text { mencapai Rumah } \\
\text { Abia }\end{array}$ & 2,3 & 2,3 & 34,1 & 56,8 & 4,5 & 4,5 & 61,4 \\
\hline 7 & Harga & - & 2,3 & 6,8 & 75,0 & 15,9 & 2,3 & 90,9 \\
\hline 8 & $\begin{array}{l}\text { Promosi yang } \\
\text { telah dilakukan }\end{array}$ & - & 9,1 & 4,5 & 31,8 & 54,5 & 9,1 & 86,4 \\
\hline
\end{tabular}

f. Kepuasan tentang kemudahan mencapai Rumah Abia

Sebagian besar $(56,8 \%)$ konsumen mengatakan kurang puas tentang kemudahan mencapai Rumah Abia dan 34,1\% mengatakan cukup puas. Meskipun lokasinya di Ciawi, namun konsumen berpendapat kurang puas dan tidak puas. Dari data diketahui bahwa sebagian besar konsumen mainan anak-anak membeli di supermarket atau toko mainan dan pedagang keliling di sekolahan. Kemudahan mencapai kedua tempat tersebut jauh lebih baik daripada ke Rumah Abia. Dengan demikian, PT STB perlu memikirkan tambahan outlet pemasaran yang lebih dekat ke kota Bogor, sehingga lebih mudah didatangi orang tua dengan anaknya yang masih kecil.

g. Kepuasan responden tentang harga

Sebagian besar (75\%) konsumen mengatakan kurang puas tentang harga yang diberlakukan di Rumah Abia dan 15,9\% tidak puas. Produk PT STB bermutu ekspor, maka berimplikasi pada peningkatan harga. Kondisi ini mengakibatkan produk mainan anak-anak dari kayu tersebut menjadi mahal untuk pasar domestik. Data tersebut memberi gambaran kepada perusahaan untuk mensegmentasikan pasar bagi konsumen, yaitu produk berharga Rp50.000 ke bawah diperuntukkan untuk konsumen menengah ke bawah dan produk berharga di atas Rp50.000 diperuntukkan untuk konsumen menengah ke atas.

h. Kepuasan tentang promosi dan media promosi Sebagian besar $(54,5 \%)$ konsumen mengatakan kurang puas dengan media promosi yang dilakukan selama ini dan 31,8\% tidak puas. Berdasarkan jawaban tersebut diketahui konsumen menghendaki promosi melalui majalah anak-anak (31,8\%) dan demo di sekolahan $(38,6 \%)$ sebagaimana dimuat pada Tabel 6 .

Untuk itu PT STB perlu mengembangkan media promosi, yaitu melakukan demo ke sekolah TK potensial (TK yang berpeluang berkunjung ke lokasi pemasaran PT STB) dan memasang iklan pada majalah/tabloid anakanak seperti Bobo, Kids, Donald Bebek. Perusahaan tetap mempertahankan promosi yang ada saat ini, yaitu internet dan pameran untuk media bagi segmen pasar menengah ke atas.

Tabel 6. Media promosi yang diinginkan konsumen

\begin{tabular}{|c|c|c|c|}
\hline No. & Media Promosi & $\begin{array}{l}\text { Jumlah } \\
\text { (orang) }\end{array}$ & $\begin{array}{l}\text { Persentase } \\
(\%)\end{array}$ \\
\hline a & TV & 2 & 4,5 \\
\hline$b$ & $\begin{array}{l}\text { Iklan pada TV } \\
\text { Plasma }\end{array}$ & 4 & 9,1 \\
\hline c & Radio & 3 & 6,8 \\
\hline d & $\begin{array}{l}\text { Majalah anak- } \\
\text { anak/Buletin/Surat } \\
\text { kabar }\end{array}$ & 14 & 31,8 \\
\hline e & Internet & 4 & 9,1 \\
\hline $\mathrm{f}$ & $\begin{array}{l}\text { Demo ke sekolah- } \\
\text { sekolah }\end{array}$ & 17 & 38,6 \\
\hline
\end{tabular}

\section{Analisis Atribut Prioritas}

Dalam bisnis penting diketahui pertimbangan konsumen membeli suatu produk, termasuk produk mainan anak-anak dari limbah kayu yang diproduksi PT STB. Dalam penelitian ini pertimbangan tersebut dibatasi pada harga, mutu produk, merek, daya tarik unsur pendidikan, daya tarik penggunaan warna cerah dalam mainan anak-anak, promosi yang dilakukan, kemudahan memperoleh mainan anak-anak dari limbah kayu, variasi disain dan munculnya disain 
baru. Untuk mengetahui urutan prioritas konsumen dalam membeli mainan, dilakukan dengan analisis Thurstone dan rinciannya disajikan pada Tabel 7 dan Gambar 1. Berdasarkan analisis Thurstone, diuraikan atribut produk yang paling diprioritaskan sampai tidak diprioritaskan konsumen dalam pertimbangan pembelian mainan anak-anak.

Tabel 7. Skala Thurstone berdasarkan urutan kepentingan prioritas pembelian

\begin{tabular}{clc}
\hline Urutan & Atribut Prioritas & Skala \\
\hline 1 & Merek & 0,62 \\
2 & Harga & 0,56 \\
3 & Munculnya disain baru & 0,50 \\
4 & Daya tarik kecerahan warna & 0,29 \\
5 & Mutu/kualitas/ketahanan & 0,26 \\
6 & Daya tarik unsur pendidikan & 0,20 \\
7 & Variasi Disain & 0,15 \\
8 & Promosi yang dilakukan & 0,04 \\
9 & Kemudahan memperoleh & 0,00 \\
& mainan & \\
\hline
\end{tabular}

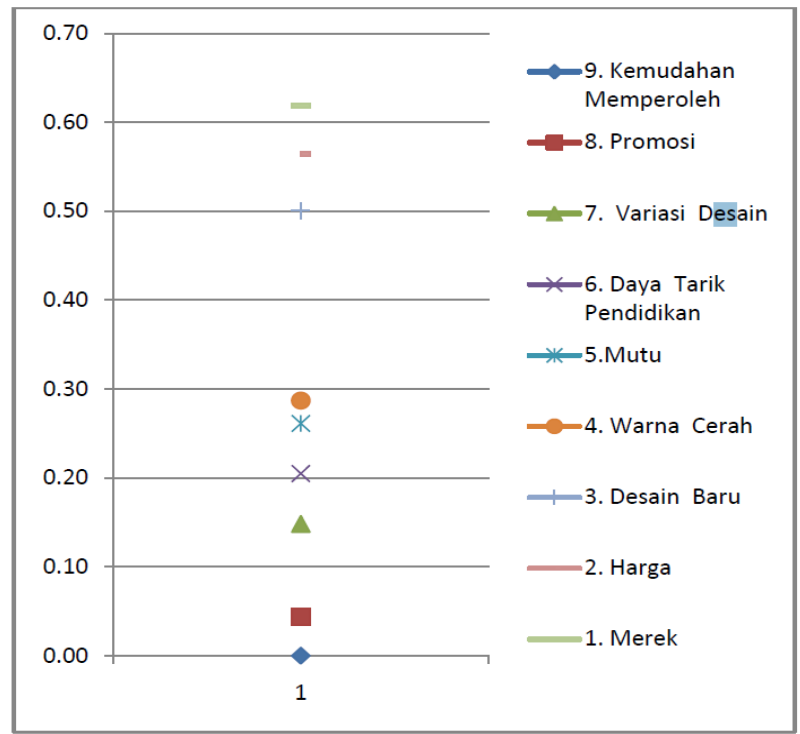

Gambar 1. Skala Thurstone pada atribut prioritas pembelian mainan

a. Pertimbangan merek

Merek dagang merupakan tanda untuk menunjukkan kepada pembeli tentang perusahaan penghasil produk yang bersangkutan, disamping itu merupakan bagian penting dari produk (Sutojo, 2009). Hal ini sejalan dengan hasil analisis Thurstone pada atribut merek yang merupakan pertimbangan prioritas pertama dalam pembelian mainan anak-anak dari limbah kayu dengan skala 0,62 atau skala tertinggi (Tabel 7). Bagi sebagian besar konsumen merek dagang dapat menjadi jaminan produk yang dibeli memberikan manfaat menurut yang dibutuhkan dan diinginkan. Dari segi psikologis sosial merek barang dapat memberikan kepuasan tersendiri bagi konsumen, karena merasa dirinya tergolong dalam kelas sosial tertentu. Untuk meningkatkan produk dalam pengembangan usaha, PT STB harus memperhatikan penggunaan merek produk yang dihasilkan. Mengingat PT STB adalah perusahaan dalam kategori UKM maka perusahaan dianjurkan memberi merek dengan mengkombinasikan nama perusahaan PT STB atau Rumah Abia dengan merek yang telah digunakan PT STB, misalnya Hampelhans Rumah Abia" dan "The Chekies Rumah Abia". Manfaat yang dihasilkan dari pemberian merek dengan kombinasi merek adalah memperkenalkan produsen kepada konsumen, sehingga kesan konsumen dapat lebih mengenal produk Rumah Abia; kemudahan produsen dalam memperkenalkan produk baru dan manfaat yang tidak kalah pentingnya adalah menjadi media promosi bagi produsen. Hal yang berbeda untuk pasar ekspor, biasanya pesanan dengan job order, yaitu si buyer (pembeli) memesan dengan mengirim disain, sehingga penggunaan merek untuk ekspor tidak terlalu penting.

b. Pertimbangan Harga

Harga merupakan pertimbangan prioritas kedua dalam pembelian mainan dengan skala Thurstone 0.56 atau skala kedua tertinggi (Tabel 7 dan Gambar 1). Berdasarkan hasil evaluasi pasca pembelian yang dilakukan konsumen setelah berkunjung dan membeli mainan di Rumah Abia, terlihat bahwa 75\% kurang puas terhadap harga (Tabel 8). Untuk meningkatkan penjualan dan mempertahankan pelanggan agar tidak beralih kepada produk lain, maka perusahaan perlu mempertimbangkan penurunan harga menurut harga rerata pendapat responden.

c. Pertimbangan munculnya desain baru Salah satu hal yang penting diperhatikan dalam produk mainan adalah keragaman produk berupa munculnya desain produk baru. Apabila inovasi dalam desain produk baru kurang berkembang, maka produk mainan yang ada tidak bertambah (hanya ituitu saja) dan membosankan, sehingga konsumen kurang berminat membelinya. Berkembangnya inovasi produk baru sangat tergantung dari tenaga perancang yang mampu menghasilkan desain-desain kreatif. Dalam hal 
Tabel 8. Tingkat kepuasan konsumen terhadap produk mainan anak di Rumah Abia

\begin{tabular}{llccccccc}
\hline No & \multicolumn{1}{c}{ Uraian } & $\begin{array}{c}\text { Sangat } \\
\text { Puas } \\
(\%)\end{array}$ & $\begin{array}{c}\text { Puas } \\
(\%)\end{array}$ & $\begin{array}{c}\text { Cukup } \\
\text { puas } \\
(\%)\end{array}$ & $\begin{array}{c}\text { Kuran } \\
\text { g puas } \\
(\%)\end{array}$ & $\begin{array}{c}\text { Tidak } \\
\text { puas } \\
(\%)\end{array}$ & $\begin{array}{c}\text { Jumlah } \\
\text { sangat puas } \\
\text { dan puas }(\%)\end{array}$ & $\begin{array}{c}\text { Jumlah } \\
\text { kurang puas } \\
\text { dan tidak } \\
\text { puas (\%) }\end{array}$ \\
\hline 1 & Aneka ragam produk & 2.3 & 9.1 & 70.5 & 18.2 & 0 & 11.4 & 18.2 \\
2 & Mutu produk & 6.8 & 65.9 & 18.2 & 6.8 & 2.3 & 72.7 & 9.1 \\
3 & Unsur pendidikan & 4.5 & 13.6 & 75.0 & 6.8 & - & 18.2 & 6.8 \\
4 & Merek & - & 6.8 & 20.5 & 70.5 & 2.3 & 6.8 & 72.7 \\
5 & Lokasi pemasaran & - & 9.1 & 11.4 & 15.9 & 63.6 & 9.1 & 79.5 \\
6 & Kemudahan mencapai & 2.3 & 2.3 & 34.1 & 56.8 & 4.5 & 4.5 & 61.4 \\
7 & Rumah Abia & - & 2.3 & 6.8 & 75.0 & 15.9 & 2.3 & 90.9 \\
8 & Harga & - & 9.1 & 4.5 & 31.8 & 54.5 & 9.1 & 86.4 \\
\hline
\end{tabular}

memunculkan desain baru, masih menghadapi tantangan terbatasnya tenaga desain industri kreatif termasuk desain mainan anak-anak (ITB, 2003).

d. Pertimbangan daya tarik penggunaan warna cerah

Produk mainan anak-anak berbasis kayu yang diproduksi PT STB mempunyai keunikan atau daya tarik dalam unsur pendidikan dan penggunaan warna cerah. Hal ini sejalan dengan perkembangan fisiologis anak pada umumnya yaitu anak usia 2-6 tahun senang dengan bentuk dan warna cerah akibat penggunaan warna cerah yang memberikan rangsangan mata pada anak-anak (Hurluck, 1990). Dalam kaitan tersebut, sangat erat hubungan psikologi perkembangan anak dengan penggunaan warna, serta disain mainan. Ketiga hal tersebut harus menjadi satu kesatuan yang harus dimiliki seorang perancang, agar mainan anakanak menciptakan daya tarik.

e. Pertimbangan mutu

Manfaat yang diperoleh perusahaan dari upaya pengembangan mutu produk adalah dapat menarik lebih banyak konsumen yang menjadikan mutu sebagai salah satu motivasi dalam pembelian. Berdasarkan urutan prioritas ini, perusahaan diharapkan terus mengembangkan mutu produk yang memberikan manfaat buat konsumen. Berdasarkan hasil evaluasi pasca pembelian, 65,9\% konsumen puas dengan mutu atau ketahanan produk perusahaan (Tabel 8). Tingginya tingkat kepuasan konsumen akan mutu produk dapat dimengerti, mengingat PT STB pada awalnya berorientasi ekspor yang tentunya memiliki mutu ekspor, sehingga mainan anak yang diproduk- si PT STB lebih tinggi dibandingkan mutu produk sejenis di pasar lokal.

f. Pertimbangan unsur pendidikan

Salah satu keunggulan Rumah Abia adalah menyediakan permainan dari kayu yang terkait dengan unsur pendidikan, seperti merakit bagian-bagian mainan menjadi satu kesatuan yang utuh, mendesain mainan anakanak dengan motif/gambar flora dan fauna yang memiliki unsur pendidikan pengenalan flora dan fauna kepada anak usia dini dan merangsang kreativitas anak. Hasil wawancara memperlihatkan alasan utama orang tua membeli mainan anak-anak dari limbah kayu karena adanya keunikan atau daya tarik unsur pendidikan dalam mainan anak yang dapat mempercepat atau menguatkan kemampuan kecerdasan anak seperti kemampuan motorik, konsentrasi dan kreativitas. Seusai penelitian Usman et al (2010), bahwa 87\% konsumen membeli produk mainan edukatif untuk meningkatkan kemampuan dan keterampilan (potensi) anak sesuai dengan usianya.

Berdasarkan hasil evaluasi pasca pembelian, 70,5\% konsumen mengatakan cukup puas dengan adanya kandungan unsur pendidikan dalam mainan anak-anak dari kayu yang diproduksi PT STB (Tabel 8). Dengan demikian perusahaan perlu mempertahankan dan bahkan mengembangkan daya tarik unsur pendidikan menjadi keunggulan produk PT STB.

g. Pertimbangan variasi desain

Variasi disain adalah keragaman rancangan produk, misalnya produk mainan mobilmobilan didesain menjadi berbagai model yang menarik bagi anak-anak. Dengan demiki- 
an terjadi peningkatan jumlah (alternatif) pilihan produk bagi konsumen.

h. Pertimbangan Promosi

PT STB perlu mengembangkan media promosi, yaitu melakukan demo ke sekolah TK potensial atau TK yang berpeluang akan berkunjung ke lokasi pemasaran PT STB dan memasang iklan pada majalah/tabloid anakanak seperti Bobo, Kids, Donald Bebek, dengan tetap mempertahankan promosi yang ada saat ini, yaitu internet dan pameran.

i. Pertimbangan kemudahan memperoleh

mainan

Sampai saat ini lokasi penjualan/pemasaran produk mainan anak-anak dari limbah kayu masih dipasarkan di Rumah Abia atau di satu lokasi saja. Jadi produk mainan anak-anak dari limbah kayu produk PT STB belum dipasarkan di toko mainan. Dari data tersebut, perlu dikembangkan lokasi pemasaran melalui dipertimbangkan menjalin kerjasama dengan toko mainan anak di mall atau supermarket.

\section{Strategi Pemasaran}

Secara umum strategi pemasaran yang perlu dilakukan perusahaan adalah merumuskan kembali segmen pasar yang menjadi fokus layanan. Selama ini perusahaan hanya fokus melayani segmen pasar dari golongan kelas sosial menengah ke atas, sedangkan segmen pasar menengah ke bawah kurang diperhatikan. Hasil analisis Thurstone pada atribut prioritas, diketahui bahwa faktor-faktor yang menjadi urutan atribut prioritas sebagai pertimbangan konsumen dalam pembelian mainan anak-anak dari limbah kayu berturut-turut adalah merek, harga, munculnya desain baru, daya tarik penggunaan warna cerah, mutu, kandungan unsur pendidikan, variasi desain, kemudahan memperoleh mainan dan promosi. Berdasarkan faktor yang diinginkan tersebut, maka disusun strategi peningkatan produk untuk atribut terkait dengan produk berikut:

a. Merek

Sebagian produk telah bermerek chekies dan hampelhang, namun sisanya belum diberi merek. Strategi pengembangan produk untuk merek pada produk yang belum bermerek adalah perusahaan mengembangkan kombinasi produk merek yang telah ada selama ini dengan nama perusahaan, yaitu chekies Rumah Abia atau hampelhang Rumah Abia. Strategi pengembangan merek ini sekaligus bermanfaat untuk mempromosikan produk PT STB, sehingga tidak perlu mengeluarkan biaya promosi yang sangat mahal.

b. Harga

Segmen pasar yang dilayani perusahan sekarang terbatas pada segmen kelas menengah ke atas, yaitu dapat dilihat dari yang berkunjung ke Rumah Abia hanya sekolah TK bergengsi. Padahal banyak sekolah TK dari kelas menengah ke bawah yang perlu digarap perusahaan untuk meningkatkan pangsa pasar dan pada gilirannya akan meningkat total volume penjualan. Strategi yang perlu dilakukan PT STB adalah strategi penetapan harga (price determination strategy) untuk segmen pasar menengah ke atas dan segmen pasar menengah ke bawah. Pada umumnya segmen pasar menengah ke atas tidak terlalu berpengaruh dengan harga lebih tinggi, tetapi segmen ini akan sensitif dengan mutu, sehingga strategi yang perlu dilakukan untuk segmen pasar menengah ke atas adalah peningkatan mutu. Untuk segmen pasar kelas menengah ke bawah sangat terpengaruh dengan tingkat harga (elastisitas harga), artinya apabila harga diturunkan, maka jumlah yang belanja dari segmen menengah ke bawah kemungkinan akan meningkat. Strategi yang dilakukan adengan menurunkan harga menurut harga rerata $(9,34 \%)$ dari harga yang telah ditetapkan perusahaan.

c. Desain baru

Salah satu kekurangan industri kreatif, termasuk mainan anak dari kayu adalah kurangnya inovasi produk akibat kurangnya desaindesain baru, sementara anak usia 2-6 tahun menginginkan produk yang selalu baru karena perkembangan usianya yang selalu ingin mengetahui sesuatu. Strategi pengembangan produk untuk desain baru adalah menambah produk jenis baru yang belum pernah diproduksi sebelumnya, dengan bentuk atau ukuran dan harga lebih rendah dari jenis produk lain yang pernah dipasarkan. Hal ini dilakukan dengan pertimbangan potensi permintaan produk di segmen pasar yang cukup kuat, namun daya beli konsumen dalam segmen pasar lebih rendah bila dibandingkan dengan segmen pasar yang telah dilayani sebelumnya. Mengingat anak usia 2-6 tahun memiliki kecenderungan untuk mengetahui hal-hal baru dengan tetap mempertahankan mutu dan kandungan unsur pendidikan yang merupakan ciri khas/keunikan PT STB maka perusaha- 
an secara periodik perlu mengembangkan desain baru dalam pengembangan usahanya. Untuk inovasi produk baru penting diperhatikan pelatihan tenaga perancang.

d. Daya tarik kecerahan warna

Secara umum anak-anak usia 2-6 tahun memiliki ketertarikan pada bentuk dan warna suatu benda dan jauh lebih besar pengaruhnya daripada fungsi benda tersebut. Ketertarikan warna bersifat murni hasil rangsangan yang kuat pada mata anak-anak, maka daya tarik kecerahan warna menjadi salah satu keunggulan PT STB. Strategi yang akan dilakukan adalah mengembangkan kombinasi warna cerah yang dapat memikat anak-anak untuk memiliki mainan warna-warna cerah dengan tanpa menghilangkan unsur pendidikan dalam mainan.

e. Mutu

PT STB memproduksi mainan anak-anak yang memperhatikan mutu, mulai dari bahan baku, proses pembuatan, komposisi penggunaan cat dan kecerahan warna, ketahanan dan keamanan bagi anak-anak. Strategi yang digunakan adalah perusahaan diharapkan terus mengembangkan mutu produk yang memberikan manfaat buat konsumen/pembeli dan mempertahankan mutu yang telah ada sebagai salah satu keunggulan PT STB, sekaligus meningkatkan mutu menurut segmen pasar layanan.

f. Unsur pendidikan

Anak-anak usia 2-6 adalah anak yang baru memasuki dunia pendidikan dan merupakan awal mula pembentukan karakter pada diri anak, sehingga pada usia ini, anak-anak lebih senang menghabiskan waktunya bermain. Untuk itulah diperlukan mainan yang dapat merangsang kreativitas anak. Sejalan dengan target pasar PT STB adalah sekolah TK, maka kandungan unsur pendidikan yang dimiliki produk mainan menjadi daya tarik tersendiri sebagai keunikan yang ditawarkan perusahaan. Strategi yang digunakan adalah mengembangkan kandungan unsur pendidik-an pada mainan anak-anak, karena merupakan keunikan atau ciri khas dari desain yang diproduksi PT STB.

g. Variasi desain

Produk mainan anak-anak yang diproduksi PT STB sangat bervariasi atau beragam, yaitu memproduksi 31 jenis mainan anak-anak. Walaupun mainan yang diproduksi sudah cukup bervariasi atau beragam, perusahaan harus mempertimbangkan produk yang di- inginkan pelanggan agar tidak beralih pada produk lain. Strategi yang dilakukan adalah perusahaan mempertahankan variasi desain yang telah ada dan mengembangkan variasi desain produk baru lainnya.

h. Promosi

Promosi ikut memegang peranan penting dalam memberikan pengaruh terhadap penjualan. Dari data pembelian mainan limbah kayu di Rumah Abia, 56,8\% pembelian diputuskan anak-anak dan 43,2\% diputuskan orang tua. Data ini mengindikasikan sasaran promosi adalah anak-anak dan orang tua, sehingga perlu dirancang agar sasaran tersebut dapat dipengaruhi secara efektif. Dalam kaitannya dengan media promosi, 38,6\% mengatakan agar promosi dilakukan melalui demo di sekolah dan 31,8\% agar promosi dilakukan melalui majalah anak-anak.

Berdasarkan uraian di atas, untuk meningkatkan volume penjualan, dilakukan strategi promosi berikut: (1) pemberian hadiah seperti gantungan kunci kepada konsumen yang telah berbelanja Rp100.000-Rp200.000; (2) mengembangkan promosi melalui personal selling, yaitu melakukan interaksi langsung penjual dengan sekolah TK potensial, misalnya pada saat sekolah mengumpulkan orang tua (tahun ajaran, penerimaan raport atau halal bi halal); (3) mengembangkan promosi melalui hubung-an masyarakat dan publisitas, melalui penyediaan berita komersial tentang produk Rumah Abia di suatu media yang disiarkan di TV atau radio atau panggung (biasanya pada saat pameran tanpa dibayar sponsor); (4) mengembangkan promosi melalui iklan pada majalah anak-anak seperti Bobo, Donald Bebek dan Tabloid Kids.

i. Kemudahan memperoleh mainan

Sampai saat ini jumlah tempat pemasaran produk mainan PT STB hanya di Rumah Abia. Berkaitan dengan hal tersebut, strategi yang akan dilakukan adalah (1) mempertahankan tempat penjualan saat ini dan menjalin kerja sama dengan toko mainan anak-anak yang terdapat pada pusat pertokoan/mall untuk memasarkan produk pada toko tersebut dengan sistem pembayaran yang telah disepakati kedua belah pihak; (2) menjalin kerjasama dengan sekolah TK potensial dalam pemasaran produk PT STB. Secara ringkas strategi pemasaran produk mainan anak-anak yang akan dilakukan dapat dilihat pada Tabel 9. 
Tabel 9. Strategi pemasaran produk mainan anak-anak yang akan dilakukan perusahaan

\begin{tabular}{|c|c|}
\hline Atribut & Strategi yang dilakukan \\
\hline Merek & $\begin{array}{l}\text { Mengembangkan kombinasi merek produk antara merek yang telah ada selama ini dengan } \\
\text { nama perusahaan seperti chekies Rumah Abia atau hampelhan Rumah Abia. Strategi ini } \\
\text { bermanfaat untuk mempromosikan produk PT STB. }\end{array}$ \\
\hline Harga & $\begin{array}{l}\text { Untuk segmen menengah ke bawah menurunkan harga 9,34\% dari harga yang ditetapkan } \\
\text { perusahaan. }\end{array}$ \\
\hline Disain baru & $\begin{array}{l}\text { - Menambah produk jenis baru yang belum pernah diproduksi sebelumnya, yang bentuk } \\
\text { atau ukuran dan harga lebih murah dari jenis produk lain yang pernah dipasarkan. } \\
\text { - Inovasi produk baru untuk memberikan variasi desain alternatif pilihan bagi pelanggan } \\
\text { dan pelatihan tenaga desainer/perancang. }\end{array}$ \\
\hline Mutu & $\begin{array}{l}\text { Mengembangkan mutu produk yang memberikan manfaat buat konsumen/pembeli dan } \\
\text { mempertahankan mutu/kualitas yang telah ada sebagai salah satu keunggulan PT. STB. }\end{array}$ \\
\hline Unsur pendidikan & $\begin{array}{l}\text { Mengembangkan kandungan unsur pendidikan yang terdapat pada mainan anak-anak, } \\
\text { karena merupakan keunikan atau ciri khas dari desain yang diproduksi PT. STB. }\end{array}$ \\
\hline Promosi & $\begin{array}{l}\text { - Mengembangkan promosi melalui personal selling, yaitu melakukan interaksi langsung } \\
\text { antara penjual dengan sekolah TK potensial, misalnya pada saat sekolah mengumpulkan } \\
\text { orang tua (tahun ajaran baru, penerimaan raport, dan lainnya). } \\
\text { - } \text { Mengembangkan promosi melalui iklan pada majalah anak-anak seperti Bobo, Donald } \\
\text { Bebek dan Tabloid Kids. }\end{array}$ \\
\hline $\begin{array}{l}\text { Kemudahan } \\
\text { memperoleh } \\
\text { mainan }\end{array}$ & $\begin{array}{l}\text { - Mengembangkan tempat penjualan yang ada saat ini melalui kerjasama pada toko } \\
\text { mainan anak-anak yang terdapat pada pusat perbelanjaan/pertokoan, seperti mall atau } \\
\text { supermarket yang letaknya berdekatan dengan arena bermain anak-anak. } \\
\text { - } \text { Menjalin kerjasama dengan sekolah TK potensial dalam pemasaran produk kepada } \\
\text { orangtua murid. }\end{array}$ \\
\hline
\end{tabular}

\section{KESIMPULAN}

Proses pengambilan keputusan pembelian produk mainan anak-anak dari limbah kayu dilakukan konsumen melalui tahap keputusan pembelian, yaitu pengenalan kebutuhan, pencarian informasi, evaluasi alternatif, proses pembelian dan perilaku setelah pembelian (evaluasi pasca pembelian). Berdasarkan identifikasi terhadap hasil penelitian pada kelima tahapan tersebut diperoleh faktor-faktor yang memengaruhi konsumen dalam proses pengambilan keputusan pembelian berturut-turut adalah merek, harga, desain baru (inovasi), daya tarik kecerahan warna, mutu, daya tarik unsur pendidikan, variasi disain, promosi dan kemudahan memperoleh mainan;

Berdasarkan strategi pemasaran $4 \mathrm{P}$ dan pertimbangan hasil analisis Thurstone untuk tingkat kepentingan atribut prioritas ditetapkan strategi pemasaran pengembangan usaha mainan anak-anak PT STB sebagai berikut:

1. Mengembangkan kombinasi merek produk yang telah ada dengan nama perusahaan seperti chekies Rumah Abia atau hampelhan Rumah Abia. Strategi ini sekaligus bermanfaat untuk mempromosikan produk PT STB.
2. Menurunkan harga 9,34\% dari harga yang telah ditetapkan perusahaan.

3. Menambah produk jenis baru yang belum pernah diproduksi sebelumnya, bentuk atau ukuran dan harga lebih rendah dari jenis produk lain yang pernah dipasarkan, serta inovasi produk baru dan pelatihan tenaga desainer/perancang.

4. Mengembangkan kombinasi warna cerah untuk menarik perhatian anak-anak memiliki mainan warna-warna cerah dan terus mengembangkan unsur pendidikan dalam mainan anak-anak, sebagai keunikan atau ciri khas dari desain yang diproduksi PT STB.

5. Mengembangkan mutu produk yang memberikan manfaat buat konsumen dan mempertahankan mutu yang telah ada sebagai salah satu keunggulan PT STB.

6. Mengembangkan promosi melalui personal selling dan mengembangkan promosi melalui iklan pada majalah anak-anak seperti Bobo, Donald Bebek dan Tabloid Kids atau Tabloid peluang usaha. 


\section{DAFTAR PUSTAKA}

Augustinah, F. dan A. Herawati. 2010. Pengaruh Bentuk Komunikasi Keluarga yang Dilakukan Orang Tua Terhadap Anak dalam Pembelian Produk Mainan di Kota Surabaya. Jurnal Ilmu Administrasi. VII (4): 282-296.

Biro Pusat Statistik Jawa Barat. 2009. Jawa Barat Dalam Angka

Departemen Kehutanan, 2008. Pemanfaatan Limbah Kayu, Sebagai Salah Satu Upaya Mengatasi Kelangkaan Bahan Baku. Jakarta.

Hurluck E. 1990. Psikologi Perkembangan Anak. Penerbit Erlangga. Jakarta

ITB. 2003. Tenaga Design Industri Kreatif Indonesia Masih Sangat Kurang. Jurusan Seni Rupa ITB Bandung.

Litbang Kehutanan. 2005. Pemanfaatan Limbah Kayu Disandingkan dengan HTI. Bogor.
2005. Prediksi Volume

Limbah Kayu Beberapa Industri Berbasis Kayu. Bogor.

Purwanto, D. 2011. Pembuatan Balok dan Papan dari Limbah Industri Kayu Board And Wood Block Making From Waste Of Wood Industries. Jurnal Riset Industri, V (1): 13-20.

Samian. 2008. Skala Thurstone. http://samianstats.wordpress.com/2008/0 8/15/skala-thurstone/

Sutojo S. 2009. Manajemen Pemasaran. Penerbit Damar Mulia Pustaka. Jakarta.

Usman, YP, B. Suharjo dan D. Kadarisman, 2010.Analisis Kepuasan Pelanggan Dalam Meningkatkan Kinerja Mutu Atribut Produk Mainan Edukatif (Studi Kasus: Produk 'Shofia Toys'). Jurnal Manajemen IKM, 5 (1): 90-99. 